\title{
The Functions of Code Switching in Second Language Learning Classroom
}

\author{
Albar Adetary Hasibuan, M.Phil \\ Brawijaya University \\ Indonesia \\ Risna Rianti Sari, M. Pd.I \\ Islamic State University Maulana Malik Ibrahim \\ Indonesia
}

\begin{abstract}
Nowadays, Teachers and students in bilingual school communicated mostly with native languages. The teachers should be known that if they are preparing the students' speaking ability, they must focus on encouraging them with the desired language. But sometimes, the teachers also needed to switch their language to mother tongue while second language learning class for purposes. Is this switching can increase the second language learning or the opposite; it can decrease the learning process? This article aim to present the functions of this code switching in bilingual program especially second language learning during class.
\end{abstract}

Index Term: bilinguals, classroom, code switching, second language learning

\section{Introduction}

Code switching is a common phrase that is used by bilinguals or even multilingual. Bilinguals means that the member of a community which has not only one language but it also has two or many languages instead (Indrawan, 2012). Such us Indonesia, the country which has many languages, the peoples not speak in one language but more than it, the peoples sometimes speak Indonesian language as a national language and also speak mother languages in another ocattion based on their speech event, condition and also social setting. Caused the globalization era, many bilinguals institutes was built as it possible for them to speak foreign languages beside their local languages in their daily conversations.

Code switching is often used in second language learning process. The teachers use more than one language while teach second language. They explain the theories by English or Arabic for example, and often switch the language to Indonesia as the students national language for making sure that students will understand the important message of the learning. This code switching makes it easier for students in learning second language, however its impossible for the teachers to speak second language better than their first language.

Jim Cummins argues that proficiency in language involves layer of skill and knowledge (Almaquer, 2013), the intent of this statement to gain a deeper understanding for meaning of bilingualism in learning. Bilingualism caused code switching, because a teacher who knows students language can switch his code or language in second language learning process. Wardhaugh had given the meaning of code switching that when somebody must choose a special code while speaking and he may decide to switch his code from one to another or mix them even in short sentences or maybe create new code when he speaks (Wardhaugh, 2002). This code switching in learning sometimes made a contribution for understanding second language but sometimes people believe that code switching prevents the proficiency and disturb negatively in the process of learning second language. Code switching is an important issue even in bilingualism education and also in mother tongue use. The researchers examined the various views about code switching. Pei Shi Weng said that code switching is ones of strategy in second language class in this case EFL classroom in Taiwan (Weng, 2012), in a journal which written by college of foreign language $\mathrm{Xu}$ Qing that Code switching makes big contributions to a better understanding in bilingual teaching context(Xu Qing, 2012). Mokhtar also concluded that the teachers in his research had positive attitudes towards language teaching and they have tried their best to attack their students attention by uttering some jokes and also at times code switching to enchange their students understanding (Mokhtar, 2015). 
The contrary of the researches below, some of researchers had an opposite views. Elridge assumed that code switching caused failure to use and learn the target language or unwillingness to do so, and also considered that code switching is a sign of laziness or mental sloppiness and inadequate command of language (Amorim, 2012). To a lot of educators and researchers the use of code switching is seen as a sign of weakness or lack of proficiency in the desired language (Alenezi, 2010), it is mean that if the learners of second language speak native language more than desired language will not give them opportunity to develop their second language.

In second language learning the teacher should encourage students by speaking with desired language. Moreover, in bilingual school, which the lessons delivered by foreign languages, the teacher must give a good example in speaking and understanding second language as the teacher must deliver the lesson by English. The teacher almost forbid to speak Indonesian in order the students inside can improve their second language skill and knowledge. But often the teacher also uses native language for many purposes, even for deeply understanding the theories or just for some jokes and stories. Is the code switching help the teacher in learning second language or is it because many troubles or even the code switching can decreases the learning second language process?

Islamic bilingual school in Batu is not free from that question. This school uses English and Arabic as their instruction languages. The teachers should be models in speaking foreign language in one side, and also as transformers the knowledge's in another side. As a model the teacher should encourage the student by speaking English or Arabic language, but as transformer the knowledge, the teacher sometimes need to speak students language for making sure that the knowledge were delivered. To sum up, on the basic of discussions above, there is question point involved in this study, what are the functions of code switching used in Arabic language learning class in Islamic Bilingual School Batu?

\section{Methodology}

Code switching is an interristing phenomenon in bilingual school as a very common aspect in second language learning process. There are many bilingual schools in Indonesia, even they use English and Indonesian while teaching and conversation or they use English and Arabic as Islamic bilingual school Batu. This school usually uses Arabic in Arabic language subject and the other religion subjects, and uses English in it's common subjects.

\section{Subjects}

The researcher had the opportunity to observed 23 students and interviewed two teachers of Arabic language, both of teachers were studied Arabic language in their past university and both of them have responsible to increase the Arabic language in Islamic bilingual school Batu.

\section{Instruments}

The instrument used in this research was classroom observation and interview. The researcher observed and video recorded the class conversation during Arabic language learning process to took notes on code switching between Arabic, Indonesian and other languages which involved while Arabic language learning in order the researcher can noticed the functions of code switching during class. The researcher also interviewed the teachers and some students to known their attitude toward the functions of code switching during class.

\section{Literature review}

The latest definition of code switching has no much different from previous that it is switching a language to another with specific purposes. Reyes said that the formal definition of code switching is when the use of two or more languages within a single utterance or conversation takes place (Castillo, 2014). The other definition was given by Wardhaugh that code switching is that when somebody must choose a special code while speaking and he may decide to switch his code from one to another or mix them even in short sentences or maybe create new code when he speaks (Wardhaugh, An Introductions to Socialinguistics, 2002).

\section{The Functions of Code Switching}

Wardhaugh in his book described two functions of code switching there are situational and metaphorical (Wardhaugh, An Introduction to Sociolinguistics, 2006). Situational code switching occurs when somebody switch his language based on his situation, he speaks one language in one situation and another in a different one, without change the topic. But when somebody changes the topic of speaking it is called by metaphorical, moreover some topics may be spoken in either languages.

Baker have discussed the topic of code switching from a sociolinguistics perspective, in which he listed twelve main purposes of code switching, which are relevant to bilinguals talks in general. 
Some of these functions can be observed in classroom environment and in relevance to teachers and students interactions. According to Baker, code switching can be used to underline a particular point, to change a word in place of unknown word in the target language, to show the different culture of the word in other language, to strengthen a wish, to explain a point, to express identity and communicate friendship, to lighten the atmosphere and include humor in a conversation, and in some bilingual situations, codes witching takes place when certain topics are introduced (Alenezi, 2010).

Beside both of functions of code switching below, there are many functions are popular in second language learning. According to Hymes, five basic functions of code switching there are, expressive functions, directive functions, metalinguistic functions, poetic functions, and referential functions (Weng, 2012). Expressive functions means that the teacher used code switching to express the emotions while teaching process, the teacher can showed his feelings even anger, happy, disappointment, and so on by switching his second language to students' language.

The second is directive functions, this function is used in situation when the teacher wants to order his students, and this switching can get the students' attention. When the teacher paraphrasing others' words, and some metaphors is called by metalinguistic functions. Poetic functions means that during the conversation, the teacher delivered the jokes, stories, some poetic quotations. The last functions of this code switching is referential functions which has three meaning there are lack readily available in other languages, lack semantically appropriate words in other languages, and the teachers are more familiar in their language than desired languages.

\section{Results and Discussion}

Begin from Hymes and Baker's thought about the functions of code switching in second language learning class, the researcher had modified the function especially the teacher's switching functions into four there are to reinforce the students' understanding, to express feeling during learning process, to discipline the class, and to ease tension and inject humor into a conversation. After observing class XI of Islamic Bilingual School Batu, the researcher had found many examples for code switching's functions during Arabic learning class, it will be delivered as below.

1.To reinforce the students' understanding,

To reinforce mean to clear the students' understanding toward Arabic language. The teacher must ensure the students to get what he means. The teacher in this class also switches his code from Arabic to Indonesian for some definitions, contents, grammar or meaning of sentences. Example :

T: صحيح setiap kata setelah huruf jer dibaca kasrah (every letter jer, read kasrah)

From examples above, the teacher switch his code to help the students for understanding the lessons. He switch the codes even in grammar as example above.

2. To express feeling during learning process,

The teacher used code switching to express the emotions, even his anger, his appreciate, or his disappointment toward his students. He argued that switching code to students' language was good way moreover when he want to appreciate the students' learning process. If he want to appreciate the student, for example, he switch the language from Arabic to Indonesian or even Javanese language, because the other students can understand that somebody in their class being appreciated by the teacher, so they will also motivate themselves to be better when learning process. Or when the teacher wants to express his anger, all of students will be understand what is the teacher meaning. Example :

T: Pinter, دينة باتو مشهور بماذ/؟ (Good, Batu city famous with what?).

3. To direct and discipline the class,

Using the students' language to discipline make them give the attention to the teacher. The teacher usually switch his codes before beginning the lessons when he want to conditioning the class, or while the lessons when he want to give the order for exercising or even to order the students for answering the exercise. Example :

T: No, do not sit there, you should sit in front of! Ayo Dora, apa jawabannya? (Dora, what is the answer?).

Many other examples for these functions were founded in the observation, the teacher not only switches his language from Arabic into Indonesian, but also he used Javanese language or even used English in his conversation class. He belief that this switching was the effective way for directing the students during Arabic learning class. 
4. To lighten the atmosphere and include humor in conversations.

The class not only a formal place when the learning held inside, but the class also social place when the relationship must be build from all the peoples inside. This code switching has the other functions out of second language learning process, the switching also can build the better relationship between teacher and students in or out class. The teacher argued that this better relationship can increase the students' interest toward Arabic language.

The teacher often switch his codes into Javanese language for some jokes, to cut the distance between him and his students, and the students also laugh when he deliver it. When the teacher switch his codes, the class atmosphere being warm it like the students really happy to follow his class and enjoy with Arabic language learning process. This function looked at the conversation during Arabic class as examples below. Example :

T: Klothok, لهاذا أخطأتح؟ (The answer is wrong, Why is it wrong?)

The example explained when the teacher want to say Khoto' in Arabic language which is mean wrong, he prefer to said klothok which mean one kind of fish in Javanese language.

\section{Conclusions}

Basically, the code switching has contributed many functions in second language learning process even not related with the Arabic contents, and it can be considered as a kind of useful tool in second language learning process.

\section{References}

Alenezi. Abdullah A, (2010). Students' Language Attitude Towards Using Code-Switching As A Medium Of Instruction In The College Of Health Sciences: An Exploratory Study", Arecls Vol.7, 1-22.

Almaguer,Isela and Joy Esquierdo, J. (2013). Cultivating Bilingual Learners' Language Arts Knowledge: A Framework for Successful Teaching”. International Journal of Instruction- vol.6, July (2013).

Al rowais. Hawazen, "Code Switching Between Arabic and English, Social Motivations and Structural Constraints", Thesis MA, Munche, Indiana: Ball State University, 2012.

Amorim. Rita, (2012) Code Switching in Student-Student Intearction; Function and Reason", Revista de Estudos Linguísticos da Univerdade do Porto - Vol. 7, (2012).

Indrawan, Made Iwan, Sociolinguistics study of Societies' Language, Yogyakarta: Graha Ilmu 2012.

Mokhtar.Mazlin Mohamed, (2015) Lecturers' and Students' Beliefs in Code-Switching: A Malaysian Polytechnic Context". Teflin Journal. v26il/85-96, (2015).

Olmo-Castillo. Wendy N, (2014) Teachers' Attitudes Towards Code Switching within a Bilingual Classroom. Education and Human Development Master's Theses. Paper 385.

Qing.XU, ( May 2012).A Tentative Analysis of Code Switching in College Bilingual Education. Cross-Cultural Communication, vol 8 no 4.

Susanto. Djoko, Code Switching in Indonesian Islamic Religious Discourse A Sociolinguistic Perspective, Malang: UIN Maliki Press, 2008.

Wardhaugh. Ronald, An introductions to Sociolinguistics, USA: Blackwell Publishers, 2002.,An Introduction to Sociolinguistics, $5^{\text {th }}$ ed. USA: Blackwell Publishing, 2006.

Weng. Pei-Shi, (2012). Code-Switching as a Strategy Use in an EFL Classroom in Taiwan", US-China Foreign Language, vol. 10.

Albar Adetary Hasibuan, M.Philhe was birth at Sibuhuan 11 Pebruary 1985. He studied for his first degree at ISID Ponorogo which major at religions study, and than Philosophy for his magister at Gajahmada University at Yogyakarta, Indonesia. Now he work at Brawijaya University Malang as a lecture.

Risna Rianti Sari, M.Pd.I, she was born at Kandangan on 18 April 1988. She studied both bachelor and magister in Arabic Learning Education at State of University Malang for first degree and Islamic state of University Malang for second. Now, she work at Islamic state of university Malang as an Arabic lecture. 